\title{
Zasada równego traktowania kobiet i mężczyzn w zakresie dostępu do zatrudnienia oraz warunków pracy w świetle orzecznictwa Trybunału Sprawiedliwości Unii Europejskiej
}

\section{Uwagi wprowadzające}

Zasada równego traktowania kobiet i mężczyzn jest jednym $z$ fundamentów unijnego porządku prawnego, od samego początku towarzyszącym procesowi integracji, $z$ jednej strony determinującym jego przebieg, $z$ drugiej zaś - wraz z nim ewoluującym. Najbardziej pierwotny wyraz zasady niedyskryminacji bez względu na płeć - zakaz dyskryminacji płacowej, niezbędny do urzeczywistnienia gospodarczych postulatów zacieśniania współpracy na kontynencie europejskim wraz $z$ jego przebiegiem, przez rozszerzającą wykładnię Trybunału Sprawiedliwości Unii Europejskiej - obejmował bowiem coraz to nowe obszary zabronionej dyferencjacji traktowania. Stopniowe wkraczania zakazu dyskryminacji w kolejne dziedziny życia społecznego i gospodarczego doprowadziło w rezultacie do objęcia zakresem jego zastosowania także dostępu do zatrudnienia oraz warunków pracy.

Ta ewolucja zasady równego traktowania mężczyzn i kobiet dokonała się pod wpływem licznych czynników stymulujących proces integracji tak od wewnątrz, np. akcesji do UE nowych krajowych członkowskich, jak i z zewnątrz, w szczególności aktywnego zaan- 
gażowania w działalność na rzecz równości praw przedstawicieli obu płci najważniejszych organizacji międzynarodowych - Rady Europy czy Organizacji Narodów Zjednoczonych. To właśnie pod wpływem tych czynników legislator unijny zaczął rozwijać politykę społeczną, rangą odpowiadającą polityce gospodarczej, przyjmując szereg aktów prawnych, zarówno o charakterze wiążącym, jak i reprezentujących instrumenty $z$ zakresu tzw. soft law, które kwestie równościowe wprowadziły m.in. w obszar dostępu do zatrudnienia czy szkoleń i awansów zawodowych. Przez nie unijna „ochrona przed dyskryminacją wykracza poza typową dla praw człowieka relację wertykalną i odnosi się także do wzajemnych stosunków między jednostkami” ${ }^{1}$. W konsekwencji działania Unii Europejskiej wyszły poza koncepcyjne granice formalnej równości wobec prawa, uwzględniając wymogi równości faktycznej, ukierunkowanej na korygowanie rzeczywistych nierówności² ${ }^{2}$.

Warto jednak pamiętać, że wypracowywanie równościowego acquis communautaire w odniesieniu do innych niż płacowe warunków zatrudnienia przebiegało i nadal przebiega dwutorowo, tzn. dokonuje się nie tylko przy pomocy wspomnianych aktów prawa pierwotnego czy wtórnego, ale także na drodze intensywnej działalności orzeczniczej Trybunału Sprawiedliwości Unii Europejskiej.

Celem niniejszego artykuły jest zilustrowanie sposobu, w jaki Trybunał w Luksemburgu interpretował zakaz dyskryminacji ze względu na płeć w dostępie do zatrudnienia i warunków pracy, nierzadko doprecyzowując, a nawet rozszerzając jego znaczenie przez system precedensów.

${ }^{1}$ D. Sadowska, Zakaz dyskryminacji, [w:] Prawa i wolności I i II generacji, red. A. Florczak, B. Bolechow, Toruń 2006, s. 20.

${ }^{2}$ Por. I. Boruta, Równość kobiet $i$ mężczyzn $w$ pracy $w$ świetle prawa wspólnoty europejskiej. Implikacje dla Polski, Łódź 1996, s. 17-19. 


\section{Równe traktowanie kobiet i mężczyzn w dostępie do zatrudnienia $i$ warunków pracy w orzecznictwie Trybunału Sprawiedliwości UE}

Równość traktowania kobiet i mężczyzn stanowi obecnie jedną $z$ podstawowych zasad nie tylko europejskiego prawa pracy, ale także całego systemy prawnego $\mathrm{UE}^{3}$. Nakaz równego traktowania kobiet i mężczyzn w odniesieniu do warunków pracy sięga swymi korzeniami dawnego art. 141 (119) Traktatu ustanawiającego Wspólnotę Europejską ${ }^{4}$ (obecnie art. 157 Traktatu o funkcjonowaniu Unii Europejskiej5). Jego zakres zastosowania wprawdzie nie mógł zostać bezpośrednio rozciągnięty na inne niż płacowe warunki zatrudnienia $^{6}$, niemniej jednak rozszerzająca wykładnia Trybunału Sprawiedliwości doprowadziła do ewolucyjnego przerodzenia się nakazu równej płacy w nakaz równego traktowania.

\subsection{Zasada równego traktowania kobiet i mężczyzn w dostępie do zatrudnienia - zakres zastosowania}

Obecnie podstawę prawną nakazu równego traktowania kobiet i mężczyzn w obszarze zatrudnienia stanowi dyrektywa 2006/54/ /WE7 , która $z$ dniem 15 sierpnia 2009 r. uchyliła obowiązującą w tym przedmiocie dyrektywę 76/207/EWG z 9 lutego 1976 r. ${ }^{8}$

3 Por. L. Florek, Europejskie prawo pracy, Warszawa 2010, s. 58.

4 Wersja skonsolidowana Traktatu ustanawiającego Wspólnotę Europejską, Dz.U. C 321 z 29.12.2006 r., s. 37.

5 Wersja skonsolidowana Traktatu o funkcjonowaniu Unii Europejskiej, Dz.U. C 83 z 30.03.2010 r., s. 47.

6 Por. Gabrielle Defrenne $v$. Société anonyme belge de navigation aérienne Sabena, 15.07.1978, C-149/77, ECR 1978, s. 01365, pkt 20 i n.

7 Dyrektywa 2006/54/WE Parlamentu Europejskiego i Rady z dnia 5 lipca 2006 r. w sprawie wprowadzenia w życie zasady równości szans oraz równego traktowania kobiet i mężczyzn w dziedzinie zatrudnienia i pracy (wersja przeredagowana), Dz.U. L 204 z 26.07.2006 r., s. 23.

8 Dyrektywa 76/207/EWG z dnia 9 lutego 1976 r. w sprawie wprowadzenia w życie zasady równego traktowania mężczyzn i kobiet w zakresie 
w brzmieniu nadanym dyrektywą 2002/73/WE ${ }^{9}$. W świetle wspomnianej regulacji zakazana jest wszelka bezpośrednia lub pośrednia dyskryminacja ze względu na płeć, m.in. w odniesieniu do dostępu do zatrudnienia, wykonywania zawodu, szkoleń zawodowych czy warunków pracy ${ }^{10}$. Co ważne, pojęcie dyskryminacji obejmuje na gruncie omawianej dyrektywy również molestowanie, w tym molestowanie seksualne oraz polecenie nakazujące dyskryminowanie osób ze względu na płeć ${ }^{11}$.

Tak sformułowany nakaz równego traktowania wykracza poza najczęściej spotykaną formę dyskryminacji kobiet względem mężczyzn czy nieco rzadsze sytuacje dyskryminacji mężczyzn wobec kobiet $^{12}$ i odnosi się do przesłanki bardziej ogólnej - płci, przy czym dla takiego ustalenia jego zakresu istotne znaczenie miało orzeczenie Trybunału Sprawiedliwości w sprawie $P . v . S .{ }^{13}$, dotyczącej zwolnienia osoby, która przeszła zabieg korekty płci. Trybunał nie rozpatrywał jej w odniesieniu do dyskryminacji kobiet wobec mężczyzn czy odwrotnie, ale właśnie w odniesieniu do kryterium ogólniejszego - prawa do niebycia dyskryminowanym ze względu na płeć, przypominając, że stanowi ono jedno $z$ fundamentalnych praw człowieka, którego przestrzeganie Trybunał ma obowiązek zapewnić. Zdaniem Trybunału zakres zastosowania dyrektywy 76/207/ /EWG nie mógł być ograniczony do dyskryminacji z powodu przy-

dostępu do zatrudnienia, kształcenia zawodowego i awansu oraz warunków pracy, Dz.U. L 39 z 14.02.1976 r., s. 40.

9 Dyrektywa 2002/73/WE Parlamentu Europejskiego i Rady z dnia 23 września 2002 r. zmieniająca dyrektywę Rady 76/207/EWG w sprawie wprowadzenia w życie zasady równego traktowania mężczyzn i kobiet w zakresie dostępu do zatrudnienia, kształcenia i awansu zawodowego oraz warunków pracy, Dz.U. L 269 z 05.10.2002 r., s. 15.

10 Por. art. 14 ust. 1 dyrektywy 2006/54/WE.

11 Zob. ibidem, art. 2 ust. 2.

12 Por. E. Łętowska, Równe traktowanie a granice dopuszczalności programów wyrównawczych, [w:] Równość praw kobiet i mężczyzn. Ustawodawstwo Unii Europejskiej i Rady Europy. Orzecznictwo Europejskiego Trybunału Sprawiedliwości i Europejskiego Trybunału Praw Człowiek. Teksty i komentarze, Centrum Praw Kobiet, Warszawa 2001, s. 185-186.

13 P. v S. and Cornwall County Council, 30.06.1996, C-13/94, ECR 1996, s. I-02143. 
należności do jednej lub drugiej płci, ale musiał obejmować także dyskryminację związaną z jej zmianą. Jest ona „bowiem głównie, czy nawet wyłącznie, oparta o kryterium płci. Zwolnienie $z$ pracy osoby z powodu planowanej lub zrealizowanej zmiany płci oznacza jej mniej korzystne traktowanie $\mathrm{w}$ porównaniu $\mathrm{z}$ osobami należącymi do płci, którą przed zmianą reprezentowała dana osoba"14. Tolerowanie dyskryminacji tego ostatniego rodzaju oznaczałoby natomiast brak poszanowania godności i wolności osoby. W świetle powyższego TS uznał za niezgodne $\mathrm{z}$ zasadą równego traktowania kobiet i mężczyzn w zakresie warunków pracy zwolnienie osoby transseksualnej z powodu korekty płci. Warto zauważyć, że to właśnie „w tym kontekście pojawia się po raz pierwszy w orzecznictwie Trybunału tak wyraźne odwołanie do pojęcia godności osoby jako źródła praw fundamentalnych" ${ }^{15}$.

Zakwalifikowanie przez Trybunał Sprawiedliwości Unii Europejskiej dyskryminacji osób transseksualnych jako przejawu dyskryminacji ze względu na płeć nie stanowiło jednak zapowiedzi objęcia przez niego ochroną $z$ tego samego tytułu osób homoseksualnych. Teza taka znajduje potwierdzenie w orzeczeniu w sprawie Grant ${ }^{16}$, w której powódka podniosła dyskryminacyjny charakter odmowy przyznania jej partnerce zniżki kolejowej, należnej partnerom pracowników pozostających w związkach heteroseksualnych. Trybunał uznał, że zaistniała sytuacja nie miała charakteru dyskryminacji ze względu na płeć, ponieważ nie była ona głównym kryterium różnicowania ${ }^{17}$. W konsekwencji wykluczył z zakresu zastosowania omawianej zasady przypadki nierównego traktowania oparte na orientacji seksualnej, co nie oznacza, że pozbawił osoby homoseksualne prawa do ochrony przed dyskryminacją. Zdaniem Trybunału dyskryminacja odnosząca się do kryterium orientacji seksualnej powinna być zwalczana na podstawie innych przepisów prawa unijnego. Trend zapoczątkowany orzeczeniem $P$. v. S. nie był zatem

14 Ibidem, pkt 21.

15 M. Dybowski, Prawa fundamentalne $w$ orzecznictwie ETS, C.H. Beck, Warszawa 2007, s. 177.

16 Lisa Jacqueline Grant v. South-West Trains Ltd., 17.02.1998, C-249/96, ECR 1998, s. I-0062.

17 Por. ibidem, pkt 26-28. 
kontynuowany, co więcej, wyrok w sprawie Grant jest uznawany za jeden $z$ najbardziej konserwatywnych w historii Trybunału. Jednakże znaczenie tej sprawy nie polega na jej rezultacie, ale na sposobie, w jaki TS uzasadnił swoje rozstrzygnięcie. Stanowi ono wytłumaczenie dla zmiany jego stanowiska, która musi być odczytywana w świetle wprowadzonego przez Traktat Amsterdamski do Traktatu ustanawiającego Wspólnotę Europejską art. 13 (obecnie art. 19 TFUE), przewidującego uprawnienia prawodawcze Rady w zakresie zwalczania dyskryminacji związanej m.in. właśnie $z$ orientacją seksualną ${ }^{18}$. Odmienne rozstrzygnięcie uczyniłoby zbędnym wydawanie przepisów przez Radę w tym przedmiocie.

Ochrona przyznana dyrektywą 2006/54/WE obejmuje pracowników wszystkich sektorów i gałęzi, a zatem w równym stopniu sektora prywatnego jak i publicznego ${ }^{19}$. W tej kwestii istniały orzeczenia Trybunału Sprawiedliwości wydane jeszcze przed wprowadzaniem expressis verbis takiej regulacji do prawa wtórnego.

W sprawie Marshall (I) ${ }^{20}$ Trybunał stwierdził, że art. 3 dyrektywy 76/207/EWG nie przyznawał państwu członkowskiemu prawa do ograniczenia zakresu zastosowania zasady równego traktowania kobiet i mężczyzn w obszarze jego działalności ani do poddawania go żadnym warunkom, a jako wystarczająco jasny i bezwarunkowy mógł „stanowić podstawę wystąpienia przeciwko organowi władzy państwowej działającemu w charakterze pracodawcy, celem uniknięcie zastosowania przepisu krajowego niezgodnego $z$ nim" 21 . Podobnie w orzeczeniu w sprawie Foster ${ }^{22}$ TS uznał, że artykuł ten mógł „być podstawą dochodzenia odszkodowania od instytucji, niezależnie od jej formy prawnej, która była odpowiedzialna za dostarczania usług publicznych pod kontrolą państwa i w tym celu zostały jej przyznane specjalne uprawnienia, wykraczające poza

18 Por. J. Plan̆ovová-Latanowicz, Trybunał Sprawiedliwości Wspólnot Europejskich i ochrona praw podstawowych, Warszawa 2000, s. 106.

19 Por. art. 14 ust. 1 dyrektywy 2006/54/WE.

20 M.H. Marshall v. Southampton and South-West Hampshire Area Health Authority (Teaching), 26.02.1986, C-152/84, ECR 1986, s. 0072.

21 Ibidem, pkt 56.

22 A. Foster and others v. British Gas plc., 12.07.1990, C-188/89, ECR 1990, s. I-03313. 
uprawnienia wynikające $z$ normalnych zasad regulujących stosunki między osobami” ${ }^{23}$. Trybunał przyznał więc komentowanemu artykułowi skutek bezpośredni w prawie krajowym.

Jak zostało już wcześniej wspomniane, zasada równego traktowania mężczyzn i kobiet obowiązuje w zakresie dostępu do zatrudnienia i wszystkich szczebli kształcenia i doskonalenia zawodowego, możliwości awansu oraz warunków pracy i zatrudnienia. W związku $\mathrm{z}$ tym Trybunał $\mathrm{w}$ orzeczeniu $\mathrm{w}$ sprawie Commission $v$. France ${ }^{24}$ uznał za niezgodną $z$ nią osobną rekrutację kobiet i mężczyzn na niektóre stanowiska w służbie cywilnej, przy zarezerwowaniu ustalonego odsetka miejsc dla przedstawicieli określonej płci, „kiedy prowadzi to do sytuacji, w której ograniczenie prawa podmiotowego, takiego jak prawo do równego traktowania kobiet i mężczyzn, przekracza granice konieczności osiągnięcia celu prawowitego" 25 . Trybunał Sprawiedliwości stwierdził również, że oferty pracy powinny być formułowane w sposób neutralny ${ }^{26}$. Co więcej, ochrona gwarantowana dyrektywą 76/207/EWG obejmowała zdaniem Trybunału pracowników także po ustaniu stosunku pracy ${ }^{27}$.

Tak zarysowany zakaz dyskryminacji w zakresie warunków zatrudnienia miał na celu zapewnienie równego traktowania rozumianego dosłownie, ,jako jednakowe traktowanie kobiet i mężczyzn, oraz jako brak zróżnicowania ze względu na płeć w treści przepisów prawa, w ich wykładni oraz w zakresie kryteriów i praktyk w sferze zatrudnienia"28. Dlatego też z równą mocą Trybunału w Luksemburgu uznawał za niezgodne $z$ prawem unijnym tak regulacje faworyzujące przedstawicieli płci męskiej, jak i przypadki krajowych środków prawnych zmierzających do ochrony kobiet. Doskonałym

\footnotetext{
23 Ibidem, pkt 22.

24 Commission of the European Communities v. French Republic, 20.06.1988, C-318/86, ECR 1988, s. 03559.

25 Ibidem, pkt 28.

26 Por. Commission of the European Communities $v$. Federal Republic of Germany, 21.05.1985, C-248/83, ECR 1985, s. 01459, pkt 4.

27 Por. Belinda Jane Coote v. Granada Hospitality Ltd., 22.09.1998, C-185/97, ECR 1998, s. I-05199, pkt 28.

28 E. Łętowska, op.cit., s. 185.
} 
przykładem może być orzeczenie w sprawie Stoeckel ${ }^{29}$, w którym TS potwierdził, że art. 3 dyrektywy 76/207/EWG był „wystarczająco precyzyjny, by nałożyć na państwo obowiązek niewprowadzania w drodze ustawowej zakazu pracy nocnej kobiet, nawet przy dopuszczeniu pewnych wyjątków w tym względzie, gdy praca taka nie była zabroniona mężczyznom"30. Orzeczenie to, ilustrujące rozdźwięk między prawem pracy tworzonym w ramach Międzynarodowej Organizacji Pracy a europejskim prawem pracy, doprowadziło do wypowiedzenia przez Francję Konwencji MOP nr 8931, zabraniającej pracy nocnej kobiet zatrudnionych w przemyśle, choć TS, w drodze wyjątku, dopuszczał taki zakaz w sytuacji, gdy wynikał on ze zobowiązań, jakie państwo członkowskie zaciągnęło wobec państw trzecich przed wejściem w życie $\mathrm{TWE}^{32}$. Z czasem jednakże stanowisko to uległo zaostrzeniu, a Trybunał $\mathrm{w}$ sprawie Commission $v$. France $^{33}$ stwierdził, że utrzymywanie w mocy przepisów, które zabraniają pracy nocnej kobiet w przemyśle, nie czyniąc tego wobec mężczyzn, nawet w sytuacji wypowiedzenia Konwencji MOP, stanowi naruszenia obowiązujących regulacji antydyskryminacyjnych.

\subsection{Zasada równego traktowania kobiet i mężczyzn w dostępie do zatrudnienia - wyjątki}

Nie każde różnicowanie sytuacji kobiet i mężczyzn w zakresie zatrudnienia uznane będzie za niezgodne $z$ zakazem dyskryminacji. Dyrektywa 2006/54/WE, podobnie jak czyniła to dyrektywa 76/207/EWG, przewiduje trzy wyjątki od zasady równego traktowania, przy czym pamiętać należy, że jest to wyliczenie enumera-

29 Criminal proceedings against Alfred Stoeckel, 25.07.1991, C-345/89, ECR 1991, s. I-04047.

30 Ibidem, pkt 20.

31 Por. L. Florek, Równość traktowania mężczyzn i kobiet, [w:] Równość praw kobiet i mężczyzn, s. 163.

32 Por. Criminal proceedings against Jean-Claude Levy, 2.08.1993, C-158/91, ECR 1993, s. I-04287, pkt 22.

33 Commission of the European Communities v. French Republic, 13.03.1997, C-197/96, ECR 1997, s. I-01489. 
tywne. W prawie brytyjskim znane są one pod ogólną nazwą Genuine Occupational Qualifications (GOQs), natomiast w systemie prawnym USA jako Bona Fide Occupational Qualifications $(\mathrm{BFOQs})^{34}$.

Pierwszy z dopuszczonych przypadków odmiennego traktowania dotyczy możliwości wyłączenia $z$ zakresu ochrony gwarantowanej dyrektywą tych form pracy i szkoleń zawodowych, w których ze względu na rodzaj i warunki wykonywania płeć stanowi decydujący wymóg zawodowy, $z$ tym że cel takiego odmiennego traktowania musi być zgodny $z$ prawem, a wymóg - proporcjonalny ${ }^{35}$. Sztandarowymi orzeczeniami w tym zakresie są wyroki TSUE $\mathrm{w}$ sprawie Commission v. U.K. ${ }^{36}$ oraz $\mathrm{w}$ sprawie Johnston ${ }^{37}$. W pierwszym ze wspomnianych wyroków TSUE stwierdził, że ograniczenie mężczyznom dostępu do czynności i szkoleń w zakresie położnictwa było zgodne $z$ art. 2 ust. 6 dyrektywy 76/207/EWG, choć i w tym obszarze państwa są zobowiązane do implementacji zasady równego traktowania. Ponieważ jednak względy wrażliwości osobistej w relacjach miedzy położną a pacjentką mogą odgrywać znaczną rolę w czasie porodu i po nim, brak pełnego urzeczywistnienia zasady wyrażonej w rzeczonej dyrektywie nie stanowił przekroczenia kompetencji przyznanych państwom na mocy jej przepisów ${ }^{38}$.

W drugiej z przytoczonych spraw Trybunał uznał, że w przypadku niektórych stanowisk policyjnych płeć może być czynnikiem decydującym przy ich zajmowaniu, stąd też ograniczenie w zatrudnianiu kobiet w Irlandii Północnej jako policjantek zobowiązanych do noszenia i używania broni nie przekraczało granic zakreślonych w art. 2 ust. 6 komentowanej dyrektywy, gdyż w przypadku uzbro-

34 Por. C. Bernard, Gender equality in the EU: A Balance Sheet, [w:] The EU and Human Rights, red. P. Alston, M. Bustello, J. Heen, Nowy Jork 1999, s. 242.

35 Por. art. 14. ust. 2 dyrektywy 2006/54/WE.

36 Commission of the European Communities $v$. United Kingdom of Great Britain and Northern Ireland, 8.11.1983, C-165/82, ECR 1983, s. 03431.

37 Marguerite Johnston $v$. Chief Constable of the Royal Ulster Constabulary, 15.05.1986, C-222/84, ECR 1986, s. 01651.

38 Por. Commission of the European Communities $v$. United Kingdom of Great Britain and Northern Ireland, 8.11.1983, C-165/82, pkt 20. 
jonych policjantek zdaniem Trybunału istnieje większe ryzyko napaści i utraty broni niż w przypadku uzbrojonych policjantów. Trybunał Sprawiedliwości przypomniał jednak, że wyjątek od zasady równego traktowania kobiet i mężczyzn musi być interpretowany wąsko, a jego zakres musi być oceniany w świetle zasady proporcjonalności, przy czym ocena ta należy każdorazowo do właściwości sądów krajowych. Państwo natomiast ma obowiązek okresowego rewidowania listy odstępstw od omawianej zasady, by zdecydować, czy ich utrzymywanie w świetle postępu społecznego jest konieczne ${ }^{39}$. Co więcej, wyjątki takie mogą odnosić się tylko do konkretnych stanowisk, a ich wprowadzenie musi być na tyle transparentne, by umożliwić efektywną kontrolę Komisji Europejskiej ${ }^{40}$. Kolejne odstępstwo dotyczy różnicowania sytuacji kobiet i mężczyzn ze względu na ciążę i macierzyństwo ${ }^{41}$. Norma ta, przed 2009 rokiem wyrażona w art. 2 ust. 7 dyrektywy 76/207/EWG, zgodnie ze stanowiskiem TS przedstawionym w pkt 25 uzasadnienia wyroku w sprawie Hofmann ${ }^{42}$, służyć ma ochronie biologicznego stanu kobiety w czasie ciąży i krótko po niej oraz szczególnej relacji między matką a dzieckiem, która mogłaby zostać zakłócona koniecznością szybkiego powrotu do pracy ${ }^{43}$. Stąd też przyznanie specjalnego zasiłku macierzyńskiego wyłącznie kobietom po okresie wykorzystania przez nie obowiązkowej części urlopu macierzyńskiego pozostawało $\mathrm{w}$ zgodzie $\mathrm{z}$ omawianym przepisem. Trybunał nie dopatrzył się również naruszenia zakazu dyskryminacji płciowej w obszarze zatrudnienia w regulacjach przyznających tylko kobiecie adoptującej dziecko prawo do 3-misięcznego urlopu macierzyńskiego, jako że znajdowały one uzasadnienie w trosce o jak najpełniejsze zrównanie tej sytuacji $z$ sytuacją rzeczywistych narodzin

39 Por. Marguerite Johnston v. Chief Constable of the Royal Ulster Constabulary, 15.05.1986, C-222/84, pkt 36-39.

40 Por. Commission of the European Communities v. French Republic, 20.06.1988, C-318/86, pkt 25.

41 Por. art. 28 ust. 1 dyrektywy 2006/54/WE.

42 Ulrich Hofmann v. Barmer Ersatzkasse, 12.07.1984, C-184/83, ECR 1984, s. 03047.

43 Por. ibidem, pkt 25. 
dziecka ${ }^{44}$. Za zgodne $\mathrm{z}$ zasadą równego traktowania Trybunał uznał również przepisy wprowadzające zakaz pracy nocnej kobiet w ciąży, zastrzegając jednocześnie, że nie mogą stać się one podstawą rozwiązania $z$ kobietą ciężarną umowy o pracę na czas nieokreślony tylko dlatego, że w ich świetle nie może ona wykonywać przez pewien czas pracy nocnej ${ }^{45}$. W sprawie Dekker ${ }^{46}$ Trybunał stwierdził, że zasadę równego traktowania narusza

odmowa zatrudnienia przez pracodawcę kandydata płci żeńskiej, odpowiedniego do wykonywania danej pracy, z obawy przed niekorzystnymi następstwami zatrudnienia kobiety w ciąży, związanymi z przepisami przyjętymi przez władze publiczne, które zrównują niezdolność do pracy z powodu ciąży i porodu z niezdolnością do pracy z powodu choroby ${ }^{47}$.

Jego zdaniem odmowa zatrudnienia kobiety z powodu ciąży, jako oparta na kryterium mającym zastosowanie wyłącznie do kobiet, stanowi dyskryminację bezpośrednią, której jakiekolwiek próby usprawiedliwienia są niedopuszczalne. W świetle powyższego uzasadnione staje się pytanie, czy nienawiązanie stosunku pracy lub zwolnienie $z$ pracy $\mathrm{w}$ sytuacji nieobecności $z$ powodu okoliczności charakterystycznych tylko dla jednej płci zawsze będzie miało charakter dyskryminujący. Odpowiedź na nie przynosi wyrok Trybunału w sprawie Hertz $^{48}$, w którym uznano za zgodne $z$ nakazem równego traktowania mężczyzn i kobiet rozwiązanie stosunku pracy w przypadku nieobecności spowodowanej chorobą pozostającą w związku z wcześniejszą ciążą lub porodem. Ponieważ w sytuacji,

44 Por. Commission of the European Communities v. Italian Republic, 20.10.1983, C-163/82, ECR 1983, s. 03273, pkt 16.

45 Por. Gabriele Habermann-Beltermann v. Arbeiterwohlfahrt, Bezirksverband Ndb./Opf. e.V, 05.05.1994, C-421/92, ECR 1994, s. I-01657, pkt. 25-26.

46 Elisabeth Johanna Pacifica Dekker v. Stichting Vormingscentrum voor Jong Volwassenen (VJV-Centrum) Plus, 8.11.1990, C-177/88, ECR 1990, s. I-03941.

47 Ibidem, pkt 14.

48 Handels-og Kontorfunktionaerernes Forbund i Danmark v. Dansk Arbejdsgiverforening, 8.11.1990, C-179/88, ECR 1990, s. I-03979. 
gdy nieobecność taka nastąpiła po wykorzystaniu urlopu macierzyńskiego, nie ma powodów do rozróżniania między chorobą spowodowaną ciążą lub porodem a każdą inną chorobą ${ }^{49}$. Kobieta pozostaje więc $\mathrm{w}$ położeniu podobnym do mężczyzny - w równym stopniu są oni narażeni na choroby, w konsekwencji wyjątek zakreślony w art. 2 ust. 7 dyrektywy 76/207/EWG nie znajdował w tym przypadku zastosowania. Jasne jest więc, że szczególne traktowanie kobiet w związku z ciążą, dopuszczone w drodze odstępstwa od zasady równego traktowania, wynika nie tylko $z$ faktu, iż jest to zjawisko charakteryzujące wyłącznie jedną płeć. U jego podstaw leży przede wszystkim przypisanie olbrzymiej wartości macierzyństwu i docenienie jego wagi dla całego społeczeństwa. Paradoksem byłoby, gdyby takiemu stanowisku towarzyszyło wykluczenie kobiet z rynku pracy ${ }^{50}$.

Trzeci wyjątek od omawianej zasady tworzą granice dopuszczalności programów afirmatywnych. Podstawą prowadzenia tzw. akcji pozytywnych jest art. 3 dyrektywy 2006/54/WE (wcześniej art. 2 ust. 8 dyrektywy 76/207/EWG), który umożliwia państwom członkowskim UE podejmowanie, „w celu zapewnienia w praktyce pełnej równości kobiet i mężczyzn w życiu zawodowym", środków przewidzianych w art. 157 ust. 4 TFUE. Warto odnotować, że zakres zastosowania tego wyjątku podlegał ewolucyjnej wykładni TSUE wraz ze zmieniającym się w tej kwestii stanowiskiem Trybunału.

W pierwszym wyroku dotyczącym tego problemu Trybunał bardzo wąsko zarysował możliwość podjęcia przez państwo działań afirmatywnych. W sprawie Kalanke ${ }^{51}$ uznał bowiem za wykraczające poza ramy dozwolonych technik wyrównawczych przepisy przyznające automatycznie pierwszeństwo w zatrudnieniu lub awansie kobietom, w sytuacji jednakowych kwalifikacji kandydatów przeciwnych płci, jeśli tylko liczba kobiet zatrudnionych w danym sektorze nie przekracza 50\%. Wydaje się, że do takiego rozstrzygnięcia

49 Por. ibidem, pkt 16.

50 Por. P. Craig, G. de Búrca, EC Law: Text, Cases \& Materials, Nowy Jork 1996, s. 851.

51 Eckhard Kalanke v. Freie Hansestadt Bremen, 17.10.1995, C-450/93, ECR 1995, s. I-03051. 
doprowadziło specyficzne podejście Trybunału w Luksemburgu do możliwości stosowania programów wyrównawczych, które traktował on jako wyjątek od zasady równego traktowania, w związku z czym, jak każdy wyjątek, musiały być one interpretowane ściśle. W konsekwencji przyznanie kobietom absolutnego i bezwarunkowego pierwszeństwa przy zatrudnianiu i awansie wykraczało zdaniem TS poza promocję równych szans. Co więcej, system zmierzający do osiągnięcia równej reprezentacji kobiet i mężczyzn na wszystkich szczeblach zatrudnienia wprowadzał w drodze substytucji równość rezultatów, choć właściwe przepisy przewidywały wyłącznie równość szans ${ }^{52}$. Tym samym Trybunał, uznając za dopuszczalny wyjątek wyrównywanie jedynie tych ostatnich, zanegował prawowitość koncepcji równości materialnej.

Nieco łagodniejsze stanowisko zajął TS w sprawie Marshall ${ }^{53}$, w której uznał ustawodawstwo Nadrenii-Westfalii, przewidujące pierwszeństwo kobiet w awansie w służbie publicznej, gdy ich reprezentacja w porównaniu $\mathrm{z}$ mężczyznami na danym stanowisku była mniejsza, oboje kandydaci mieli takie same kwalifikacje i nie było szczególnych okoliczności przeważających szalę na korzyść mężczyzn, za zgodne $z$ art. 2 ust. 8 dyrektywy 76/207/EWG. Trybunał przypomniał wprawdzie, że możliwość stosowania programów wyrównawczych stanowi derogację prawa indywidualnego, a ich zgodność $z$ art. 2 ust. 8 wymaga, by nie przyznawały one absolutnego i bezwarunkowego pierwszeństwa kobietom, pominął jednakże kwestię obowiązku ścisłej interpretacji tego wyjątku. Stwierdził także, że regulacje obowiązujące na terenie landu, w przeciwieństwie do tych, które stanowiły przedmiot rozstrzygnięcia w sprawie Kalanke, pozwalały na poddanie kandydatów mających identyczne kwalifikacje obiektywnej ocenie $z$ punktu widzenia wszelkich istotnych kryteriów i przełamanie pierwszeństwa kobiety w sytuacji, w której jedno lub kilka $z$ nich przechylało szalę na korzyść mężczyzn. Kryteria te nie mogły być jednak dyskryminujące w odnie-

52 Por. ibidem, pkt. 22-23.

53 Hellmut Marschall v. Land Nordrhein-Westfalen, 11.11.1997, C-409/ /95, ECR 1997, s. I-06363. 
sieniu do pań ${ }^{54}$. Trybunał Sprawiedliwości przychylił się również do argumentacji rządu Nadrenii-Westfalii, że przewidziana przez prawo klauzula generalna stanowiła jednocześnie formę walki z uprzedzeniami i stereotypami dotyczącymi roli i zdolności kobiet w życiu zawodowym, które powodują, że nawet gdy kandydaci przeciwnych płci mają te same kwalifikacje, awansowani są raczej mężczyźni ${ }^{55}$.

W kolejnym orzeczeniu Trybunał w Luksemburgu zdystansował się jeszcze bardziej od nieprzychylnego systemowi kwotowemu wyroku w sprawie Kalanke. W sprawie Badeck ${ }^{56}$ uznał bowiem za zgodne $z$ art. 2 ust. 1 i ust. 8 dyrektywy 76/207/EWG m.in. unormowanie krajowe, które w przypadku jednakowych kwalifikacji kandydatów przeciwnych płci przyznaje pierwszeństwo kobietom, jeśli jest to niezbędne dla realizacji planu promowania kobiet, gdy powody o większej wadze prawnej się temu nie sprzeciwiają, a kandydaci poddani są obiektywnej ocenie uwzględniającej ich sytuacje osobiste. Zmianę podejścia TS uzasadniać może fakt, że system ten, zwany flexible result quotas, ukierunkowany jest na osiągniecie określonego rezultatu w określonym przedziale czasowym, a nie jest, w przeciwieństwie do tzw. flexible women's quotas, którego dotyczyły dwa wcześniejsze orzeczenia, wskazówką proceduralną ${ }^{57}$. $Z$ kolei granice akcji pozytywnych podejmowanych przez państwo zostały zarysowane w orzeczeniu w sprawie Abrahamsson ${ }^{58}$, w którym TS stwierdził, że w świetle postanowień traktatowych programy wyrównawcze nie mogą być realizowane przy pomocy metod nieproporcjonalnych do zamierzonego celu ${ }^{59}$. Za takie uznał natomiast regulacje wprowadzające obowiązek zatrudnienia osoby mającej

54 Por. ibidem, pkt. 31-33.

55 Por. ibidem, pkt 29.

56 Georg Badeck and Others, interveners: Hessische Ministerpräsident and Landesanwalt beim Staatsgerichtshof des Landes Hessen, 28.03.2000, C-158/97, ECR 2000, s. I-01875.

57 Por. M. Wandzel, Równe traktowanie kobiet i mężczyzn, Kraków 2006, s. 129 .

58 Katarina Abrahamsson and Leif Anderson v. Elisabet Fogelquist, 6.07.2000, C-407/98, ECR 2000, s. I-05539.

59 Por. ibidem, pkt 55. 
wystarczające kwalifikacje, ale niższe niż kontrkandydat, w sytuacji gdy należy on do płci niedostatecznie reprezentowanej, a różnica w kwalifikacjach nie jest na tyle duża, by możliwe było stwierdzenie naruszenia obiektywizmu w wyborze.

\subsection{Zasada równego traktowania kobiet i mężczyzn w dostępie do zatrudnienia a zakaz dyskryminacji płciowej w obszarze zabezpieczenia społecznego}

Z dotychczasowych rozważań widać, że Trybunał w Luksemburgu nadał wymogowi jednakowego traktowania mężczyzn i kobiet w zakresie dostępu do pracy i warunków zatrudnienia bardzo szeroki zakres, implikujący nie tylko konieczność wąskiej interpretacji wyjątków od niego ${ }^{60}$, ale także sytuację, w której regulacje dyrektywy 76/207/EWG nakładają się na sferę znajdującą się pod reżimem innych dyrektyw, mianowicie sferę zabezpieczenia społecznego.

Pierwszą sprawą, którą w tym kontekście zajmował się Trybunał, była sprawa Burton ${ }^{61}$. Trybunał Sprawiedliwości uznał w niej, że zasada równego traktowania kobiet i mężczyzn rozciąga się także na warunki nabycia prawa do odprawy $z$ tytułu dobrowolnego odejścia $z$ pracy, gdyż w świetle dyrektywy 76/207/EWG pojęcie zwolnienia musiało być interpretowane w sposób szeroki, obejmujący również rozwiązanie stosunku pracy w ramach programu dobrowolnych redukcji. Fakt, że możliwość taka istniała jedynie w okresie 5 lat poprzedzających osiągnięcie minimalnego wieku emerytalnego, różnego dla kobiet i mężczyzn, nie stanowiło samo w sobie naruszenia rzeczonej dyrektywy ${ }^{62}$. Prawo do odprawy przysługiwało bowiem $w$ równym stopniu bez względu na płeć, $z$ wyjątkiem ustalenia odmiennego wieku uprawnionych, co zgodne jest $z$ art. 7

${ }^{60}$ Por. W. Czapliński, R. Ostrihansky, P. Saganek, A. Wyrozumska wybór i redakcja, Prawo Wspólnot Europejskich. Orzecznictwo. Wydanie nowe z Suplementem, Warszawa 2005, s. 920.

${ }^{61}$ Arthur Burton v. British Railways Board, 16.02.1982, C-19/81, ECR 1982, s. 00554.

62 Por. ibidem, pkt 18 ust. 1 i 2. 
dyrektywy 79/7/EWG ${ }^{63}$, nienaruszającym prawa państw członkowskich do swobodnego ustalania wieku emerytalnego, w celu przyznania emerytury i wynikających stąd możliwych skutków dla innych świadczeń. Szeroki zakres przedmiotowy pojęcia zwolnienia obejmuje również zdaniem Trybunału Sprawiedliwości politykę pracodawcy ustalającą określony wiek, z którego osiągnięciem następuje przymusowe rozwiązanie stosunku pracy. Konsekwentnie, zwolnienie kobiety tylko $z$ tego powodu, że osiągnęła ona wiek uprawniający do nabycia emerytury, jeżeli wiek ten jest zróżnicowany dla kobiet i mężczyzn, oznaczał dyskryminację ze względu na płeć niezgodną z dyrektywą 76/207/EWG ${ }^{64}$. Zasada ta orzeczeniem w sprawie Beets-Proper ${ }^{65}$ została także rozciągnięta na pracodawców prywatnych. Dodatkowo Trybunał stwierdził, że państwo członkowskie nie może

wyłączyć z zakresu zastosowania zasady równego traktowania wyraźnych lub dorozumianych warunków umowy o pracę zawartej na podstawie układu zbiorowego pracy, które prowadzą do rozwiązania tej umowy z chwilą osiągnięcia przez zatrudnionego określonego wieku, ustalanego w odniesieniu do wieku emerytalnego, różnego dla kobiet i mężczyzn ${ }^{66}$.

W sposób ogólny zależność między zasadą równego traktowania bez względu na płeć w obszarze zatrudnienia i zabezpieczenia społecznego została przez TS wyrażona w sprawie Jackson and Cresswell $^{67}$, w której stwierdził on, iż system świadczeń nie podlegał wyłączeniu z zakresu zastosowania dyrektywy 76/207/EWG tylko $z$ tego powodu, że pozostawał formalnie częścią państwowego sys-

63 Dyrektywa 79/7/EWG z dnia 19 grudnia 1978 r. w sprawie stopniowego wprowadzania w życie zasady równego traktowania kobiet i mężczyzn w dziedzinie zabezpieczenia społecznego, Dz.U. L 6 z 10.01.1979, s. 24.

64 Por. M.H. Marshall v. Southampton and South-West Hampshire Area Health Authority (Teaching), 26.02.1986, C-152/84, pkt 38.

65 Vera Mia Beets-Proper v. F. Van Lanschot Bankiers NV, 26.02.1986, C-262/84, ECR 1986, s. 00773.

66 Ibidem, pkt 40.

67 Sonia Jackson et Patricia Cresswell v. Chief Adjudication Officer, 16.07.1992, C-63-64/91, ECR 1992, s. I-04737. 
temu zabezpieczenia społecznego. Przedmiot takiego systemu musiał jednakże dotyczyć dostępu do zatrudnienia, szkoleń zawodowych i awansów oraz warunków pracy ${ }^{68}$.

\subsection{Zasada równego traktowania kobiet i mężczyzn w dostępie do zatrudnienia - konsekwencje naruszenia}

Istotną kwestią w przypadku zasady równego traktowania kobiet i mężczyzn w zakresie warunków pracy jest problem skutków jej naruszenia. Obecnie problematyki tej dotyczy art. 18 dyrektywy 2006/54/WE (dawniej art. 6 ust. 2 dyrektywy 76/207/EWG). Pierwotna wersja przepisów przewidujących wymóg równego traktowania bez względu na płeć nie nakładała jednakże na państwa obowiązku wprowadzenia określonych sankcji, wyrażając jedynie ogólny postulat zapewnienia osobie uważającej się za ofiarę naruszenia omawianej zasady, możliwości dochodzenia roszczeń przed sądem, po wyczerpaniu drogi przed innymi właściwymi organami. Trybunał w Luksemburgu doprecyzował jednak znaczenie tego wymogu, uznając w sprawie Colson ${ }^{69}$, że środki te powinny być na tyle skuteczne, by zapewnić realizację celów dyrektywy oraz możliwość faktycznego powoływania się na nie przed sądami krajowymi $^{70}$. Pomimo pozostawienia swobody w wyborze sankcji dyrektywa wymagała także zdaniem Trybunału, wyrażonym w sprawie Dekker, „by w przypadku, gdy państwo członkowskie wybierze sankcję w postaci odpowiedzialności cywilnej, jakiekolwiek naruszenie zakazu dyskryminacji było samo w sobie wystarczające, aby uznać pełną odpowiedzialność osoby jej winnej oraz by nie były uwzględniane żadne podstawy do jej wyłączenie, obowiązujące w prawie krajowym"71. Trybunał Sprawiedlowości uznał jednak, że

\footnotetext{
68 Por. ibidem, pkt. 27 i 28.

69 Sabine von Colson and Elisabeth Kamann v. Land Nordrhein-Westfalen, 10.04.1984, C-14/83, ECR 1984, s. 01891.

70 Por. ibidem, pkt 18.

71 Elisabeth Johanna Pacifica Dekker $v$. Stichting Vormingscentrum voor Jong Volwassenen (VJV-Centrum) Plus, 08.11.1990, C-177/88, pkt 26.
} 
dyrektywa nie przewidywała w przypadku naruszenia zasady równego traktowania nałożenia na pracodawcę obowiązku zatrudnienia dyskryminowanego kandydata, a także nie zawierała wyraźnej podstawy dochodzenia odszkodowania, gdy nie zostało ono przewidziane przepisami prawa krajowego. Natomiast w sytuacji, w której państwo zdecydowało się połączyć naruszenie zasady równego traktowania $z$ możliwością dochodzenia odszkodowania, musiało „być ono adekwatne do doznanej szkody i powinno przewyższać czysto nominalne pokrycie strat"72. Usunięcie skutków dyskryminacji może natomiast nastąpić albo w drodze ograniczenia przywilejów osobom, którym one wcześniej przysługiwały, albo poprzez poprawę sytuacji grupy dyskryminowanej ${ }^{73}$.

\section{Uwagi końcowe}

Nakaz równego traktowania mężczyzn i kobiet w zakresie dostępu do pracy i warunków zatrudnienia jest, jak widać, przedmiotem bogatego orzecznictwa Trybunału Sprawiedliwości w Luksemburgu, z którego wyraźnie wynika, że promowanie równość płci plasuje się wysoko w politycznej hierarchii priorytetów Unii Europejskiej ${ }^{74}$. $Z$ drugiej jednak strony konieczność ciągłego zaangażowania Trybunału w rozwiązywanie sporów wyrosłych na gruncie regulacji równościowych dowodzi istnienia problemów $z$ właściwą implementacją zakazu dyskryminacji płciowej w tej dziedzinie. Przyczyny tego są różne. Część autorów podnosi, że jest to wynik bardzo formalnego, numerycznego ujęciem równości, zgodnie z którym kobiety i mężczyźni są równi pod każdym względem, przy czym równość

72 Sabine von Colson and Elisabeth Kamann v. Land Nordrhein-Westfalen, 10.04.1984, C-14/83, pkt 28.

73 Por. Constance Christina Ellen Smith and others v. Avdel Systems Ltd., 28.09.1994, C-408/92, ECR 1994, s. I-04435, pkt. 16 i 21.

74 Por. Równość szans kobiet i mężczyzn. Doświadczenie krajów kandydujacych i wyzwania zwiazane $z$ akcesja do Unii Europejskiej, Program Monitoringu Akcesji do Unii Europejskiej (UE), Open Society Institute, Warszawa 2002, s. 12. 
jest tutaj postrzegana $z$ męskiej perspektywy, a zatem jednakowe traktowanie oznacza przestrzeganie męskich norm i wymagań ${ }^{75}$. A może bardziej odpowiednim środkiem osiągnięcia równości byłoby „nierówne traktowanie sytuacji nierównych, co samo w sobie prowadzi właśnie do równego traktowania" ${ }^{76}$ ?

Ogromną rolę $\mathrm{w}$ udzielaniu odpowiedzi na powyższe pytanie odgrywa TSUE, swymi orzeczeniami doprecyzowujący znaczenie zakazu dyskryminacji ze względu na płeć, w tym również w sferze zatrudnia. Jego wpływ na unijne prawo do równego traktowanie był i jest tak znaczący, że w istocie stało się ono prawem precedensowym. Ów proces judykalizacji równościowego acquis communautaire został zapoczątkowany przez nadanie zasadzie równego traktowania bez względu na płeć charakteru niewynikającego explicite $z$ pierwotnych regulacji traktatowych, mianowicie przez jej podniesienie do rangi zasady podstawowej ${ }^{77}$. Szczególnie uwidacznia się to na gruncie zakazu dyskryminacji w zakresie dostępu do pracy i warunków zatrudnienia, który TS najpierw wyprowadził z zakazu dyskryminacji płacowej, a następnie rozwijał przez system precedensów, nierzadko stanowiących impuls dla legislatora unijnego do ich ujęcia $\mathrm{w}$ formie wiążących przepisów odpowiednich aktów prawa wtórnego. I choć niektóre rozstrzygnięcia Trybunału w tym przedmiocie budzą krytykę albo jako niespójne $z$ linią orzeczniczą, albo jako niewystarczające do wykorzenianiu dyskryminacji płciowej, to trzeba mieć na względzie fakt, że jego zadanie nie było łatwe. Nie dotyczyło bowiem oceny kwestii równościowych in abstracto, ale wymagało wypracowania balansu między dwoma podstawowymi obszarami integracji: polityką społeczną i polityką gospodarczą.

75 Por. B. Bercusson, European Labour Law, Londyn 1996, s. 176.

${ }^{76}$ E. Łętowska, op.cit., s. 188.

77 Por. R. Cichowski, Sex Equality, [w:] A. Stone Sweet, The Judicial Construction of Europe, Nowy Jork 2004, s. 176 oraz 191 i 194. 


\section{SUMMARY}

\section{The principle of equal treatment for men and women as regards access to employment and working conditions in the light of the judicial decisions of the Court of Justice of the European Union}

The principle of equal treatment for men and women is the unquestionable foundation of the European Union legal order. It accompanied the process of the European integration from the very beginning, on the one hand determining its direction, on the other - being shaped by the process of European integration as its gradual development implied the successive extension of its scope of application to new areas such as access to employment and working conditions.

The aim of this article is to present the way in which the Court of Justice of the European Union construed the prohibition of gender discrimination as regards the terms of employment, quite often specifying or even extending its meaning through the system of precedents.

In this aim the article concentrates on the scope of application of the equal treatment principle in employment and occupation regardless of sex, accepted exceptions to it and legal consequences of the infringement of this principle.

Keywords: sex discrimination, access to employment and working conditions, equal treatment for men and women, exceptions to the prohibition of gender discrimination, protection of women in relation to pregnancy and maternity, male and female workers 